\title{
MINERALOGICAL STUDY OF SEDIMENT SAMPLES OF KACHUA, CHANDPUR DISTRICT FOR INVESTIGATION OF ARSENIC BEARING MINERALS
}

\author{
NASIR AHMED, MOHAMMAD MIKAIL \\ Isotope Hydrology Division, Institute of Nuclear Science \& Technology, Atomic Energy \\ Research Establishment, Ganakbari, Savar, Dhaka, Bangladesh
}

AND

D. K. SAHA

Materials Science Division, Atomic Energy Centre, Dhaka 1000, Bangladesh

\begin{abstract}
Sixteen sediment samples of different depth (up to $122 \mathrm{~m}$ ) were studied by X-ray diffraction (XRD) method. The samples were collected from a test borehole, which was drilled by Bangladesh Water Development Board (BWDB) at Kachua, Chandpur district. All the samples were characterized and different minerals have been identified in the samples. Quartz is the major mineral and was found to be in the range of 54.97 - $97.88 \%$. Two arsenic bearing minerals namely, iron arsenate, $\mathrm{Fe}_{2} \mathrm{As}\left(\mathrm{AsO}_{4}\right)_{3}$ and arsenic selenide telluride, $\mathrm{AsSe}_{0.5} \mathrm{Te}_{2}$ were found in the samples of depth $55.20 \mathrm{~m}$ and $100.60 \mathrm{~m}$, respectively. Bangladesh Atomic Energy Commission (BAEC) in collaboration with the United States Geological Survey (USGS) conducted the groundwater sampling campaign for shallow and deep tubewells in Kachua upazila. From the hydro-chemical results, the concentrations of arsenic in shallow tubewells were found above the maximum permissible limit (50 ppb). Concomitantly, the mineralogical study of sediment samples in the same area reflects that the shallow aquifers of Kachua upazila are contaminated by arsenic due to the presence of arsenic bearing minerals.
\end{abstract}

\section{INTRODUCTION}

Clean drinking water supply is a basic requirement in primary health care in Bangladesh and groundwater is the dominant source of it. During the last 30 years about 4 million hand tubewells were installed in shallow aquifer to provide pathogen free drinking water. $^{(1)}$ Simultaneously, for self-sufficiency in food, the cultivation of high yielding variety of rice spread all over the country and large number of deep and shallow tube wells for irrigation were sunk. Most of shallow tubewells are reported contaminated with arsenic. ${ }^{(1,2)}$ Arsenic, in general, occurs widely in natural environments (air, soil, rock \& minerals, and water). Scientists agree that in Bangladesh the cause of arsenic is natural (geogenic) and that it is not introduced by human activity such as mining. More than 100 arsenic bearing minerals are present and the most common are arsenopyrite (FeAsS), realgar (AsS) and orpitment $\left(\mathrm{As}_{2} \mathrm{~S}_{3}\right) \cdot{ }^{(3)}$ Other minerals containing arsenic as accessory component are also well-known, such as pyrite and iron-hydroxides. 
There are several fundamental factors in the processes of arsenic release into groundwater: one is the mineral, which bears arsenic. The second one is the environmental changes by which arsenic is released. The third one is groundwater chemistry and movements. The Japan International Cooperation Agency (JICA) team suggests that the disassociation of ferric oxy-hydroxide and release of iron and arsenic ion into groundwater occur under reduction condition. ${ }^{(4)}$ The dissolved arsenic migrates along with the movement of groundwater. The work done by the BWDB-GSB-USGS (BWDB interim report, 2003) suggests that high concentration of arsenic in the holocene sediments could be attributed to the dissolution of residual iron oxides. ${ }^{(5)}$ The low dissolved iron content is inconsistent with reductive dissolution. The arsenic enrichment of altered micas supports the association with phyllosilicates in reduced sediments.

In this context, a fundamental mineralogical study was envisaged to identify the arsenic bearing minerals in sediment. X-ray diffraction (XRD) is a versatile nondestructive analytical technique for qualitative identification and quantitative estimation of the various crystalline forms present in powdered or solid samples. ${ }^{(6)}$ In the present study XRD method was used to identify the arsenic bearing minerals in underground sediment of arsenic affected area of Kachua upazila under Chandpur district.

\section{DESCRIPTION AREA}

Kachua upazila under the Chandpur district is considered as highly arsenic affected area. Almost all the shallow hand tubewells water are highly arsenic contaminated. The test hole drilling site was selected at village Srirampur, Union-Karaia. Kachua Upazila

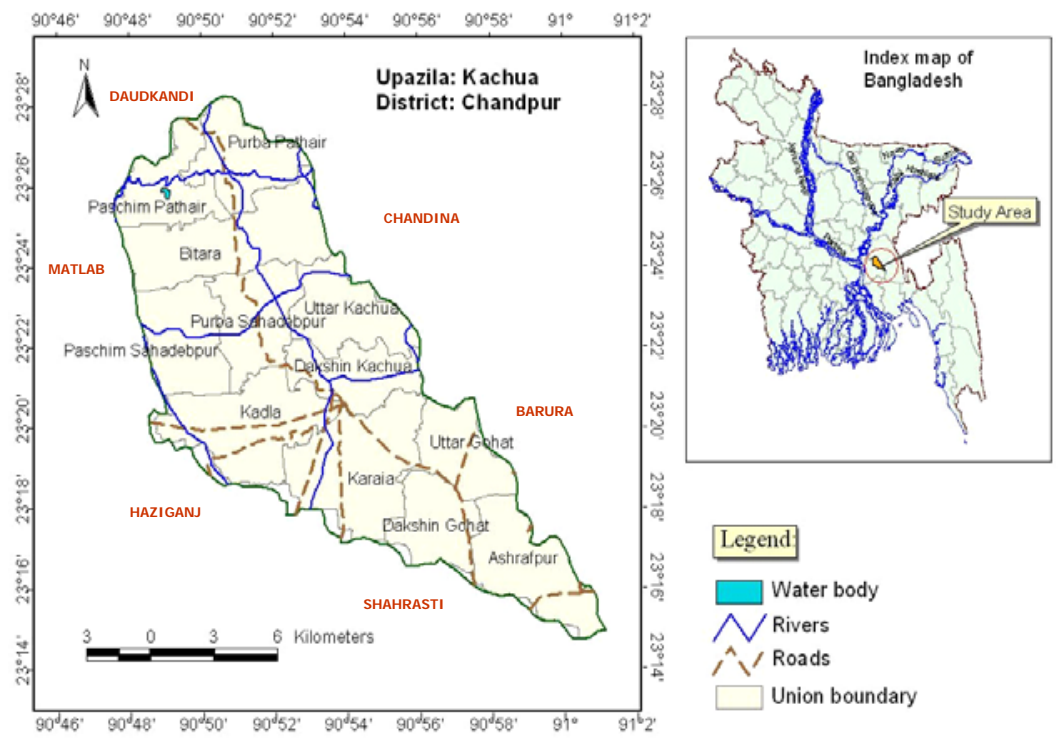

Fig. 1. Location Map of the study area.

area lies between $90^{\circ} 47^{\prime} 70^{\prime \prime}$ and $91^{\circ} 01^{\prime} 10^{\prime \prime}$ E longitude and $23^{\circ} 14^{\prime} 40^{\prime \prime}$ and $23^{\circ} 28^{\prime} 20^{\prime \prime} \mathrm{N}$ latitude covering an area of about $160 \mathrm{~km}^{2}$ with population of about 0.30 million. The 
study area of Srirampur village is located at $23^{\circ} 33^{\prime} 49.9^{\prime \prime} \mathrm{N}$ latitude and $90^{\circ} 89^{\prime} 36.3^{\prime \prime} \mathrm{E}$ longitude. The location map of study area is shown in Fig. 1. The average annual rainfall in and around the study area is about $2000 \mathrm{~mm}$ in which about $97 \%$ is received between May and October. The temperature during pre-monsoon period is the highest and rise up to $33^{\circ} \mathrm{C}$ in April. Relative humidity is high throughout the year with average $95 \%$. It is lowest in February (71\%).

\section{SAMPLE COLLECTION AND PREPARATION}

A test hole was drilled by Groundwater Hydrology, Bangladesh Water Development Board (BWDB) down to $326 \mathrm{~m}$ to assess the sediment lithology, formation thickness and aquifer properties in the study area. EDECO strata Drill Rig was used to collect the sediment samples applying the direct hydraulic rotary method. A heavy duty mud pump, FJ casings of $152 \mathrm{~mm}$ dia, $76 \mathrm{~mm}$ dia NW drilling rod, $140 \mathrm{~mm}$ dia carbide and roller bits, split spoon and Denison samplers of $76 \mathrm{~mm}$ dia etc. were used during drilling process. A number of sediment samples were collected in PVC liner. A few samples were also collected in polythene bags, which were of wash boring.

For mineralogical study purposes, the sediment samples were collected at different depth down to $122 \mathrm{~m}$. At first the collected samples were dried in an oven by fixing the temperature $65^{\circ} \mathrm{C}$. After the samples become moisture free, about $5 \mathrm{~g}$ sample was grinded to fine powder in an agate mortar and pestle to get an average particle size $<50 \mu \mathrm{m}$. An aluminum sample holder with a central groove of $15 \times 10 \times 1 \mathrm{~mm}^{3}$ dimension was used as a sample holder and the fine powdered sampłeg( placed into the groove. The surface of the sample was made sufficiently smooth using glass slide.

\section{AQUIFER SYSTEM IN THE STUDY AREA}

A lithological cross-section is drawn based on borelogs of BWDB and GSB and is presented in Fig. 2 to observe the formation thickness as well as aquifer system in the area. The aquifer system at the study site can be divided into three fairly distinct systems. The upper aquifer system or 1st aquifer is essentially the shallow aquifer, the middle or 2nd aquifer system has generally been called the deep aquifer and the deeper system or the 3rd aquifer is newly discovered at this site.

Aquiclude: The upper clay and silty clay layer, thickness varies from 5 to $7 \mathrm{~m}$, is generally grey to light grey in colour and characterized by high porosity and low permeability.

First or shallow aquifer: The shallow aquifer extends down to a thickness that varies between 35 and $70 \mathrm{~m}$. The aquifer sediments are composed of sand with lenses of clay. Water within this shallow aquifer is severely contaminated by arsenic. 
Second or deep aquifer: The second aquifer system extends beneath an aquiclude underlying the shallow aquifer down to 290 to $300 \mathrm{~m}$ depth. This deep aquifer is hydraulically connected throughout the depth and is separated from the deeper or 3rd aquifer system by a confining layer of considerable thickness. The aquifer is composed

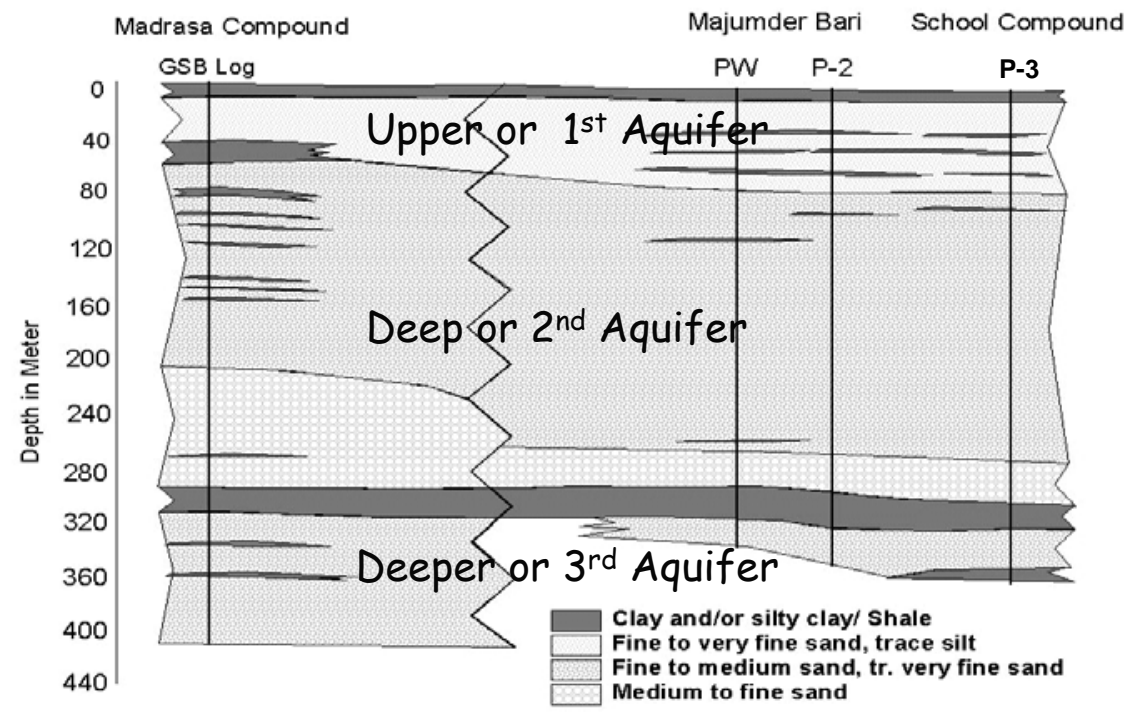

Fig. 2. Aquifer system in Srirampur area, union-Karaia, upazila-Kachua, Chandpur District (Source: BWDB).

mainly of fine to medium sand, gray to light brown in color, occasionally inter-bedded with clay bends. The thickness of this formation varies between 145 and $180 \mathrm{~m}$. The lower part of the upper aquifer consists mainly of grey medium to fine sand and extends down to 285 to $295 \mathrm{~m}$ underlain by silty clay bed. The thickness of this part ranges between 40 and $85 \mathrm{~m}$. Although the deep aquifer appears to be free of arsenic, in some areas and depths high concentrations of salt, iron, or manganese makes it unsuitable for drinking purposes.

Third or deeper aquifer: Below 10 to $15 \mathrm{~m}$ thick silty clay/shale bed the deeper (lower) or 3rd aquifer was encountered, composed mainly of grey to dark grey fine to medium sand in places alternated with thin sandy shale/clay lenses. This deeper aquifer below 285 to $295 \mathrm{~m}$ from surface is assumed to be sustainably safe and potential for good quality groundwater.

\section{EXPERIMENTAL SYSTEM}

A Philips X'Pert PRO X-ray diffractrometer was used to get X-ray data for the samples at the Materials Science Division, Atomic Energy Centre, Dhaka, with a primary beam power of $40 \mathrm{kV}$ and $30 \mathrm{~mA}$ for $\mathrm{Cu}$ radiation. A nickel filter was placed before the 
sample to reduce $\mathrm{CuK}_{\beta}$ radiation and finally $\mathrm{CuK}_{\alpha}$ radiation was only used as the primary beam. A $\theta-2 \theta$ scan was taken from 10 to $100^{\circ}$ to get possible fundamental peaks of the minerals present in the sample with the sampling pitch of $0.02^{\circ}$ and time for each step data collection was $0.6 \mathrm{sec}$. Three different samples of each depth were irradiated to get sufficient data. The XRD machine was totally computer controlled and all the data were stored in the hard disk memory of the computer for further analysis.

All the X-ray data of the sediment samples were analysed using computer software $\mathrm{X}$ 'Pert Highscore to get the interplanar spacing $d$ value of the fundamental peaks and their integrated intensity. The interplanar spacing $d$ was calculated using the formula $2 \mathrm{~d} \sin \theta=\lambda$, where $\lambda$ is the wavelength of the incident radiation and for $\mathrm{Cu}\left(\mathrm{K}_{\alpha}\right), \lambda=$ $1.54178 \AA$. All the minerals were identified correctly and their amounts were estimated within the error of maximum $\pm 1 \%$ using XRD method. Concentration of each mineral has been calculated using the following standard method. ${ }^{(7)}$ The background of the system has been determined and subtracted from the total intensity data. The total detected minerals in a sample were considered 100 per cent. Only one peak for a single mineral was selected which has the maximum peak intensity (100\% of I) among all the peaks for that particular mineral. Total integrated intensity for a particular peak was calculated using the following formula ${ }^{(7,8)}$

$$
\mathrm{I}_{\mathrm{A}}=\mathrm{I}_{\mathrm{P}} \times \mathrm{FWHM}
$$

where $I_{A}$ is the integrated intensity of a particular peak, $I_{P}$ is the peak intensity of that particular peak and FWHM is the full width at half maximum of the peak. Again,

$$
\mathrm{I}_{\mathrm{T}}=\left(\mathrm{I}_{1}+\mathrm{I}_{2}+\mathrm{I}_{3}+\ldots \ldots \ldots \ldots \ldots+\mathrm{I}_{\mathrm{n}}\right)=\sum \mathrm{I}_{\mathrm{A}}
$$

where $I_{T}$ is the total integrated intensity of the detected minerals and $A=1,2,3 \ldots \ldots$. The concentration of a particular mineral is calculated by

$$
\mathrm{C}_{\mathrm{A}}=\left(\mathrm{I}_{\mathrm{A}} / \mathrm{I}_{\mathrm{T}}\right) \times 100
$$

where $\mathrm{C}_{\mathrm{A}}$ is the concentration of a particular mineral in the sample in weight percent.

\section{RESULTS AND DISCUSSION}

Fig. 3 shows an XRD pattern of sediment sample of IHD-12 with depth $55.2 \mathrm{~m}$. In the figure, d-values were shown in the parenthesis and peaks of the minerals were identified as quartz (Q), albite (A) and iron arsenate (FeAs). The following minerals were found in the sediment samples namely, quartz, illite, albite, polyhalite, clinochlore, calcium aluminum sielicate, polylithionite-3T, sodium calcium aluminum silicate, iron arsenate and arsenic selenide telluride. The mineralogical summary of 16 sediment samples is given in Table 1. The weight percentage of quartz was found to be in the range of $54.97-97.88 \%$ as the major mineral present in the sediment samples of the test borehole at Srirumpur, Kachua, Chandpur. The weight percentage of albite was present in the range of $1.49-29.36 \%$ as the second mineral in the samples. Two arsenic bearing minerals are found in two different depths. These two minerals, such as, iron arsenate, $\mathrm{Fe}_{2} \mathrm{As}\left(\mathrm{AsO}_{4}\right)_{3}$ and arsenic selenide telluride, $\mathrm{AsSe}_{0.5} \mathrm{Te}_{2}$ were found in the depth of 55.20 
and $100.60 \mathrm{~m}$, respectively. As seen from the lithological description of test hole, these two sediment layers are composed of very fine sand to fine sand having trace of mica, silt and some dark minerals. The weight percentages of iron arsenate and arsenic selenide telluride were 1.60 and $2.12 \%$, respectively. Though their concentrations were observed in minor amount, but it shows the presence of arsenic bearing minerals in the sediment.

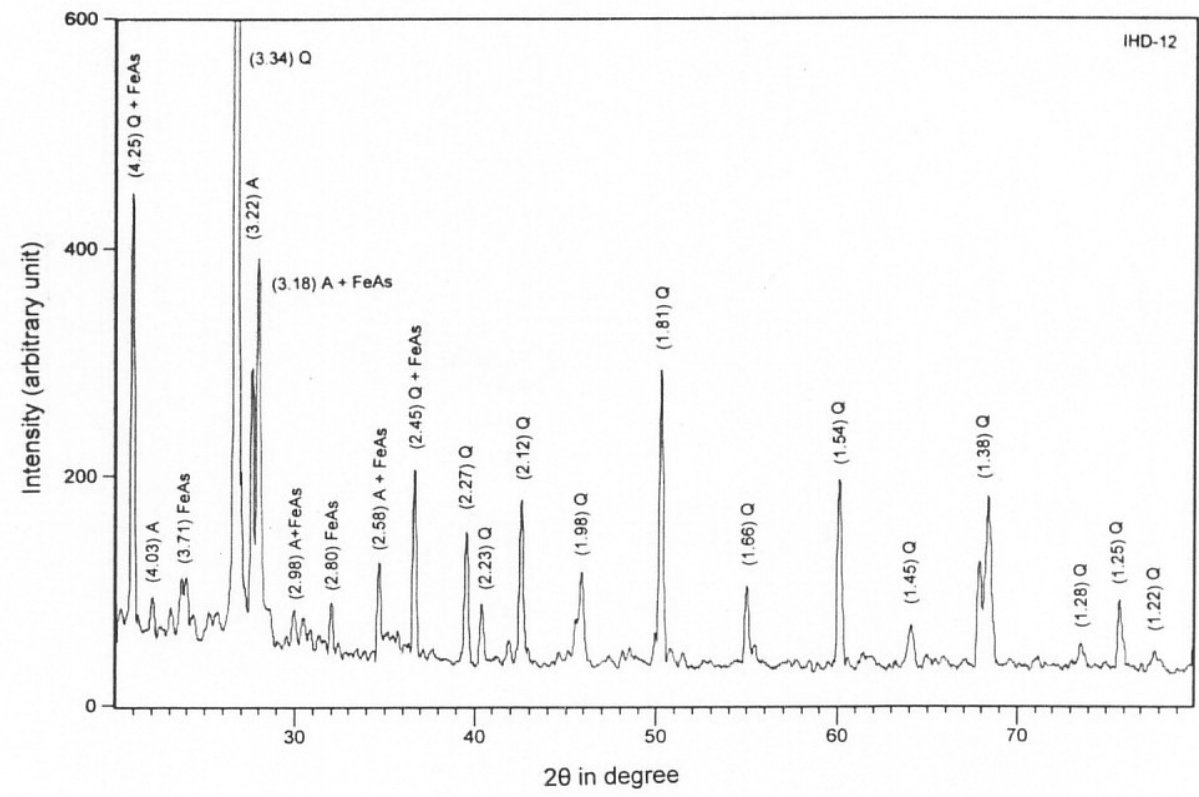

Fig. 3. XRD pattern of IHD-12 with depth $55.2 \mathrm{~m}$. containing iron arsenate.

The two dominant minerals, such as, quartz and albite were plotted with respect to depth, as seen in Figs. 4 and 5. In the case of quartz, it shows the higher concentration (89 wt.\%) near the surface and shows the decreasing trend (minimum concentration $55 \mathrm{wt} . \%$ ) up to the depth $25.0 \mathrm{~m}$. Below $25.0 \mathrm{~m}$, it has an increasing tendency both in the shallow and deep aquifer zone and the quartz concentration increases in the range of about 77 - 98 wt.\%. The maximum quartz value (97.88 wt.\%) was found in $100.6 \mathrm{~m}$ depth i.e. in the deep aquifer zone. In this same depth the arsenic bearing mineral named arsenic selenide telluride is combined.

Though the albite concentration does not follow the regular trend with respect to the depth, but it shows some variation in concentration within the band of 4 - 19 wt.\% in the same trend towards downward (Fig. 5). The maximum concentration of albite (29.36 wt.\%) was observed in the depth $15.2 \mathrm{~m}$ and simultaneously the quartz concentration was found 64.97 wt.\%. 
Table 1

Mineralogical summary of sixteen sediment samples collected from a test borehole of Srirampur, Kachua upazila

\begin{tabular}{|c|c|c|c|c|c|}
\hline $\begin{array}{l}\text { Sample } \\
\text { ID }\end{array}$ & $\begin{array}{l}\text { Depth } \\
(\mathrm{m})\end{array}$ & Minerals & $\begin{array}{l}\text { Chemical } \\
\text { formula }\end{array}$ & $\begin{array}{l}\text { Conc. } \\
\text { (wt. \%) }\end{array}$ & $\begin{array}{l}\text { Conc. } \\
\text { (gm/kg) }\end{array}$ \\
\hline \multirow[t]{3}{*}{ IHD-01 } & $3.05-3.66$ & (1) Quartz Low & $\mathrm{SiO}_{2}$ & 87.90 & 879.00 \\
\hline & & (2) Illite & $\begin{array}{l}2 \mathrm{~K}_{2} \mathrm{O} \cdot 3 \mathrm{MgO} \cdot \mathrm{Al}_{2} \mathrm{O}_{3} . \\
24 \mathrm{SiO}_{2} \cdot 12 \mathrm{H}_{2} \mathrm{O}\end{array}$ & 4.54 & 45.40 \\
\hline & & (3) Clinochlore & $\mathrm{Al}-\mathrm{Fe}-\mathrm{SiO}_{2}-\mathrm{OH}$ & 7.56 & 75.60 \\
\hline \multirow[t]{3}{*}{ IHD-15 } & 9.15 & (1) Quartz & $\mathrm{SiO}_{2}$ & 89.76 & 897.60 \\
\hline & & (2) Albite & $\mathrm{NaCaAlSi}_{2} \mathrm{O}_{7}$ & 2.54 & 25.40 \\
\hline & & (3) Orthoclase & $\mathrm{K}(\mathrm{Al}, \mathrm{Fe}) \mathrm{Si}_{2} \mathrm{O}_{8}$ & 7.70 & 77.00 \\
\hline \multirow[t]{3}{*}{ IHD-02 } & 15.25 & (1) Quartz & $\mathrm{SiO}_{2}$ & 64.97 & 649.70 \\
\hline & & $\begin{array}{l}\text { (2) Calcium aluminum } \\
\text { silicate }\end{array}$ & $\mathrm{CaO} \cdot \mathrm{Al}_{2} \mathrm{O}_{3} \cdot 2 \mathrm{SiO}_{2}$ & 5.67 & 56.70 \\
\hline & & (3) Albite & $\mathrm{Na}\left(\mathrm{AlSi}_{3} \mathrm{O}_{8}\right)$ & 29.36 & 293.60 \\
\hline \multirow[t]{3}{*}{ IHD-14 } & 24.4 & (1) Quartz low & $\mathrm{SiO}_{2}$ & 54.97 & 549.70 \\
\hline & & (2) Polylithionite- 3T & $\begin{array}{l}\mathrm{K}(\mathrm{Li}, \mathrm{Al})_{3}(\mathrm{Si}, \mathrm{Al})_{4} \\
\mathrm{O}_{10}(\mathrm{OH})_{2}\end{array}$ & 22.08 & 220.80 \\
\hline & & (3) Polyhalite & $\begin{array}{l}2 \mathrm{CaSO}_{4} \cdot \mathrm{MgSO}_{4} \cdot \\
\mathrm{K}_{2} \mathrm{SO}_{4} \cdot 2 \mathrm{H}_{2} \mathrm{O}\end{array}$ & 22.95 & 229.50 \\
\hline \multirow[t]{2}{*}{ IHD-03 } & 30.5 & (1) Quartz & $\mathrm{SiO}_{2}$ & 67.47 & 674.70 \\
\hline & & $\begin{array}{l}\text { (2) Sodium calcium } \\
\text { aluminum silicate }\end{array}$ & $\mathrm{NaCaAlSi}_{2} \mathrm{O}_{7}$ & 32.53 & 325.30 \\
\hline \multirow[t]{2}{*}{ IHD-11 } & 40 & (1) Quartz & $\mathrm{SiO}_{2}$ & 84.64 & 846.40 \\
\hline & & (2) Albite low & $\mathrm{Na}\left(\mathrm{AlSi}_{3} \mathrm{O}_{8}\right)$ & 15.36 & 153.60 \\
\hline \multirow[t]{2}{*}{ IHD-04 } & 49 & (1) Quartz & $\mathrm{SiO}_{2}$ & 95.35 & 953.50 \\
\hline & & (2) Albite & $\mathrm{Na}\left(\mathrm{AlSi}_{3} \mathrm{O}_{8}\right)$ & 4.65 & 46.50 \\
\hline \multirow[t]{3}{*}{ IHD-12 } & 55.2 & (1) Quartz & $\mathrm{SiO}_{2}$ & 80.58 & 805.80 \\
\hline & & (2) Albite low & $\mathrm{Na}\left(\mathrm{AlSi}_{3} \mathrm{O}_{8}\right)$ & 17.83 & 178.30 \\
\hline & & (3) Iron arsenate & $\mathrm{Fe}_{2} \mathrm{As}\left(\mathrm{AsO}_{4}\right)_{3}$ & 1.60 & 16.00 \\
\hline \multirow[t]{2}{*}{ IHD-05 } & 70.4 & (1) Quartz & $\mathrm{SiO}_{2}$ & 89.29 & 892.90 \\
\hline & & (2) Albite & $\mathrm{Na}\left(\mathrm{AlSi}_{3} \mathrm{O}_{8}\right)$ & 10.71 & 107.10 \\
\hline \multirow[t]{2}{*}{ IHD-13 } & 76.2 & (1) Quartz low & $\mathrm{SiO}_{2}$ & 94.45 & 944.50 \\
\hline & & (2) Albite high & $\mathrm{Na}\left(\mathrm{AlSi}_{3} \mathrm{O}_{8}\right)$ & 5.55 & 55.50 \\
\hline \multirow[t]{3}{*}{ IHD-06 } & 82.3 & (1) Quartz low & $\mathrm{SiO}_{2}$ & 76.96 & 769.60 \\
\hline & & (2) Illite & $\begin{array}{l}2 \mathrm{~K}_{2} \mathrm{O} \cdot 3 \mathrm{MgO} \cdot \mathrm{Al}_{2} \mathrm{O}_{3} . \\
24 \mathrm{SiO}_{2} \cdot 12 \mathrm{H}_{2} \mathrm{O}\end{array}$ & 6.99 & 69.90 \\
\hline & & (3) Albite high & $\mathrm{Na}\left(\mathrm{AlSi}_{3} \mathrm{O}_{8}\right)$ & 16.06 & 160.60 \\
\hline \multirow[t]{2}{*}{ IHD-07 } & 91.5 & (1) Quartz & $\mathrm{SiO}_{2}$ & 93.07 & 930.70 \\
\hline & & (2) Albite high & $\mathrm{Na}\left(\mathrm{AlSi}_{3} \mathrm{O}_{8}\right)$ & 6.93 & 69.30 \\
\hline \multirow[t]{2}{*}{ IHD-08 } & 100.6 & (1) Quartz low & $\mathrm{SiO}_{2}$ & 97.88 & 978.80 \\
\hline & & $\begin{array}{l}\text { (2) Arsenic selenide } \\
\text { telluride }\end{array}$ & $\mathrm{AsSe}_{0.5} \mathrm{Te}_{2}$ & 2.12 & 21.20 \\
\hline \multirow[t]{3}{*}{ IHD-16 } & 106.7 & (1) Quartz & $\mathrm{SiO}_{2}$ & 88.87 & 888.70 \\
\hline & & (2) Orthoclase & $\mathrm{K}(\mathrm{Al}, \mathrm{Fe}) \mathrm{Si}_{2} \mathrm{O}_{8}$ & 9.63 & 96.30 \\
\hline & & (3) Albite high & $\mathrm{Na}\left(\mathrm{AlSi}_{3} \mathrm{O}_{8}\right)$ & 1.49 & 14.90 \\
\hline \multirow[t]{3}{*}{ IHD-09 } & 112.8 & (1) Quartz low & $\mathrm{SiO}_{2}$ & 94.90 & 949.00 \\
\hline & & (2) Proustite & $\mathrm{Ag}_{3} \mathrm{AsS}_{3}$ & 0.49 & 4.90 \\
\hline & & (3) Albite & $\mathrm{Na}\left(\mathrm{AlSi}_{3} \mathrm{O}_{8}\right)$ & 4.61 & 46.10 \\
\hline \multirow[t]{2}{*}{ IHD-10 } & 122.25 & (1) Quartz low & $\mathrm{SiO}_{2}$ & 91.38 & 913.80 \\
\hline & & (2) Albite high & $\mathrm{Na}\left(\mathrm{AlSi}_{3} \mathrm{O}_{8}\right)$ & 8.62 & 86.20 \\
\hline
\end{tabular}




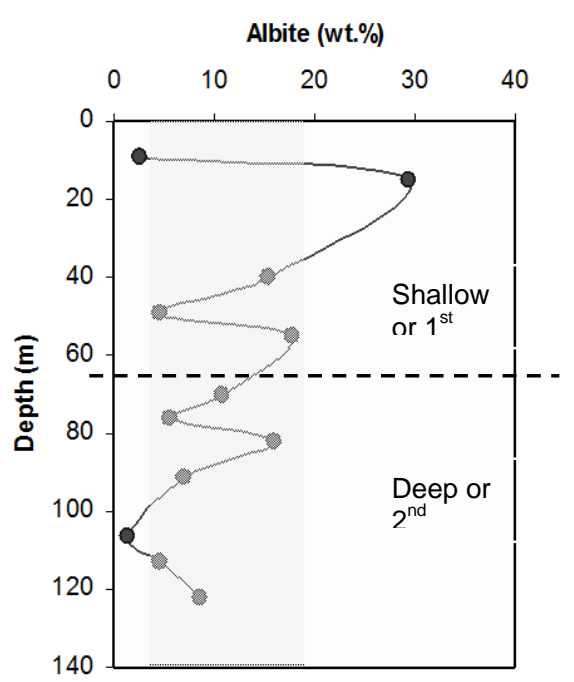

Fig. 5. Vertical distribution of albite (wt.\%) in the sediment.
Quartz (wt.\%)

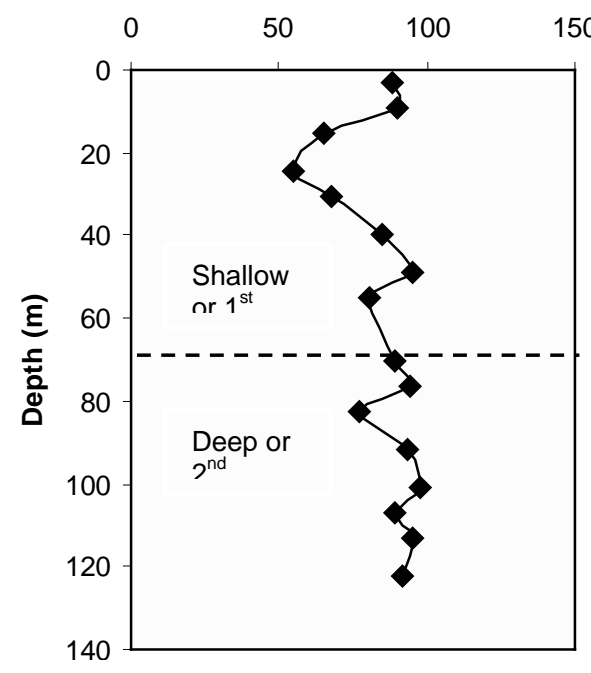

Fig. 4. Vertical distribution of quartz (wt.\%) in the sediment.

The findings of the mineralogical compositions are contrasted with the arsenic concentrations of the water samples of the shallow and deep aquifers of the same Karaia union and the vicinity unions of Kachua upazila. These water samples were collected under the joint collaboration work of Bangladesh Atomic Energy Commission (BAEC) and United States Geological Survey (USGS). The vertical distribution of As in the shallow and deep aquifers has been plotted as shown in Fig. 6 .

From Fig. 6 it is observed that the tubewells (depth range 18 - $56 \mathrm{~m}$ ) in the shallow aquifer zone are highly arsenic contaminated. It is seen that most of the deep wells (depth range $125-280 \mathrm{~m}$ ) are free from As contamination. Only three deep tubewells in the central part of Kachua upazila are found As concentration higher than the Bangladesh standard value $50 \mathrm{ppb}$. The high As contents in these three deep wells are, namely in Kachua south (As = $115 \mathrm{ppb}$ and well depth, D = $137 \mathrm{~m}$ ), in Kadla (As = $201 \mathrm{ppb}$ and D $=128 \mathrm{~m})$, and in Karaia $(\mathrm{As}=364 \mathrm{ppb}$ and $\mathrm{D}=220 \mathrm{~m})$. 


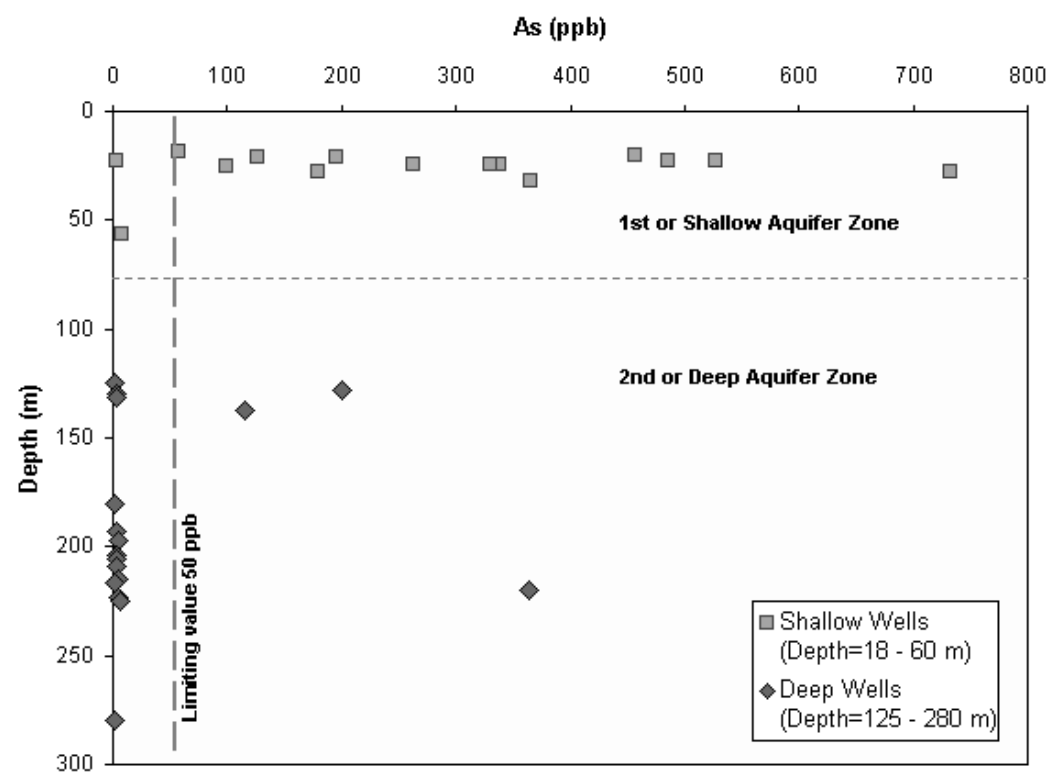

Fig. 6. Distribution of arsenic concentration in groundwater of shallow and deep aquifer zone.

To correlate the arsenic concentration of water with sediment samples, chemical analysis (XRF) has been performed on three different samples of IHD-12, IHD-08 and IHD-09 with depth of 55.2, 100.6 and $112.8 \mathrm{~m}$, respectively and data are listed in Table 2 along with XRD data after calculation. In three different sediment samples, concentration of arsenic (in wt. \%) in chemical method are in fairly good agreement with the XRD data. Fig. 7 shows XRD pattern of another arsenic bearing sediment sample of IHD-08 with depth $100.6 \mathrm{~m}$, which contains arsenic selenide telluride.

Table 2

Chemical analysis (XRF) data of arsenic for three arsenic bearing sediment samples along with XRD data

\begin{tabular}{lllcc}
\hline Sample & Minerals & Chemical formula & Arsenic concentration in wt. \% \\
\hline & & & Chemical data (XRF) & XRD data* \\
IHD-12 & Iron arsenate & $\mathrm{Fe}_{2} \mathrm{As}_{4} \mathrm{O}_{12}$ & 0.63 & 0.79 \\
IHD-08 & Arsenic selenide telluride & $\mathrm{AsSe}_{0.5} \mathrm{Te}_{2}$ & 0.38 & 0.43 \\
IHD-09 & Proustite & $\mathrm{Ag}_{3} \mathrm{AsS}_{3}$ & 0.05 & 0.07 \\
\hline
\end{tabular}

* Wt. \% of arsenic after calculation. 


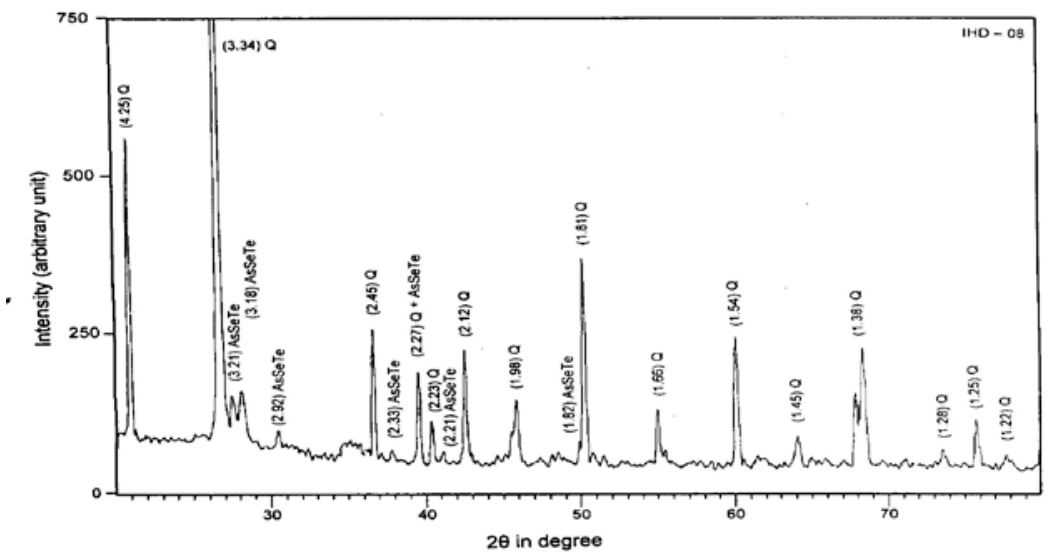

Fig. 7. XRD pattern of IHD-08 with depth $100.6 \mathrm{~m}$. containing arsenic selenide telluride.

\section{CONCLUSION}

The clay mineral fraction (found in depth 3.2, 49.0, 60.0 and $82.0 \mathrm{~m}$ ) is dominated by quartz and albite with minor illite and clinochlore. The sediment as a whole is dominated by quartz and albite. From the mineralogical study by XRD method of the sediment samples of Srirampur, Kachua, it is observed that the arsenic bearing minerals are found to be exist in the shallow and deep aquifer zone. As surveyed under the joint collaboration work of BAEC and USGS, the high arsenic contents are also identified in the groundwater of shallow tubewells and in a few deep wells in Kachua area.

\section{ACKNOWLEDGEMENT}

Authors appreciate the cooperation rendered by Mr. Alamgir Hossain, Ex-Director, Groundwater Hydrology, BWDB in providing them hydrological \& hydro-geological data and the sediment samples of the test borehole of Srirampur, Kachua. The cooperation of local DPHE office during field sampling is also acknowledged.

\section{REFERENCES}

1. D.G. KinNiburgh AND P.L. Smedeley (Eds.), BGS, DPHE, "Arsenic contamination of ground water in Bangladesh," British Geological Survey, Technical Report, WC/00/19, Keyworth, 2001.

2. Alan H. Welch, "Groundwater Quality in Two Areas of Bangladesh, Proceedings of the Symposium Behavior of Arsenic in Aquifers, Soils and Plants," organized by CIMMYT, CU, TAMU, USGS and GSB, IDB Bhaban, Dhaka, January 16-18, 2005.

3. UNDP Groundwater Survey, "The Hydrogeologic Conditions of Bangladesh," UNDP Technical Report DP/UN/BGD-74-009/1, 113, 1982.

4. KAMATA AKIRA, "Japan International Cooperation Agency (JICA), The study of groundwater development of deep aquifers for safe drinking water supply to arsenic affected areas in western Bangladesh," Final Report, 2002. 
5. "BWDB Groundwater Hydrology," Interim Report on 1st Phase of Work at Sreerampur Site, Kachua, Chandpur, Bangladesh Arsenic Mitigation Water Supply Project, 2003.

6. B. D. Cullity, "Elements of X-ray diffraction," Addison-Wesley Publishing Company, Inc., USA, 2nd Edition, 378, 1959.

7. D. K. SAHA, J. Bang. Acad. Sci., 28(1), 65, 2004.

8. D. K. Saha And S. S. Alam, J. Bang. Acad. Sci., 27(1), 37, 2003. 


\section{APPENDIX}

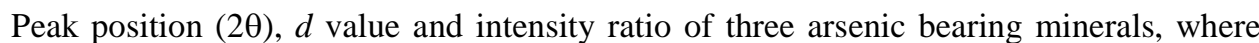
$\lambda=1.54178 \AA$.

\begin{tabular}{|c|c|c|c|c|c|c|c|c|}
\hline \multicolumn{3}{|c|}{$\begin{array}{l}\text { Iron arsenate } \\
\mathrm{Fe}_{2} \mathrm{As}_{4} \mathrm{O}_{12}\end{array}$} & \multicolumn{3}{|c|}{$\begin{array}{c}\text { Arsenic selenide telluride } \\
\mathrm{AsSe}_{0.5} \mathrm{Te}_{2}\end{array}$} & \multicolumn{3}{|c|}{$\begin{array}{l}\text { Proustite } \\
\mathrm{Ag}_{3} \mathrm{AsS}_{3}\end{array}$} \\
\hline $\begin{array}{c}2 \theta \text { in } \\
\text { degree }\end{array}$ & $\begin{array}{c}d \\
\text { value } \\
\text { in } \AA \\
\end{array}$ & $\begin{array}{c}\text { Intensity } \\
\text { ratio in \% }\end{array}$ & $\begin{array}{c}2 \theta \text { in } \\
\text { degree }\end{array}$ & $\begin{array}{c}d \text { value } \\
\text { in } \AA\end{array}$ & $\begin{array}{c}\text { Intensity } \\
\text { ratio in } \\
\%\end{array}$ & $\begin{array}{c}2 \theta \text { in } \\
\text { degree }\end{array}$ & $\begin{array}{c}d \text { value } \\
\text { in } \AA\end{array}$ & $\begin{array}{c}\text { Intensity } \\
\text { ratio in } \\
\%\end{array}$ \\
\hline 20.90 & 4.25 & 60 & 27.72 & 3.21 & 85 & 27.27 & 3.27 & 80 \\
\hline 21.87 & 4.06 & 40 & 28.01 & 3.18 & 100 & 28.15 & 3.17 & 70 \\
\hline 23.26 & 3.82 & 60 & 30.55 & 2.92 & 19 & 28.70 & 3.11 & 70 \\
\hline 23.99 & 3.71 & 100 & 38.59 & 2.33 & 24 & 32.68 & 2.74 & 100 \\
\hline 24.30 & 3.66 & 50 & 39.49 & 2.28 & 18 & 35.19 & 2.55 & 80 \\
\hline 27.86 & 3.20 & 50 & 40.70 & 2.21 & 25 & 36.22 & 2.48 & 90 \\
\hline 28.05 & 3.18 & 30 & 50.08 & 1.82 & 11 & 40.63 & 2.22 & 40 \\
\hline 29.89 & 2.98 & 60 & & & & 46.07 & 1.97 & 40 \\
\hline 31.96 & 2.80 & 80 & & & & 47.34 & 1.92 & 40 \\
\hline 34.63 & 2.58 & 45 & & & & 49.25 & 1.85 & 30 \\
\hline 36.68 & 2.45 & 80 & & & & 55.34 & 1.66 & 30 \\
\hline 41.34 & 2.18 & 90 & & & & 58.40 & 1.58 & 30 \\
\hline
\end{tabular}

Journal of Bangladesh Academy of Sciences, Vol. 32, No. 1, 1-12, 2008 